\title{
Radiographic and ultrasonographic imaging of a dystrophic mineralization on the oblique sesamoidean ligament in a jumping horse. Twenty months follow-up
}

\section{Acompanhamento radiográfico e ultrassonográfico de calcificação distrófica no ligamento sesamoideo oblíquo em cavalo de salto. Seguimento durante 20 meses}

\author{
Marilia Ferrari Marsiglia $^{1}$ (D); Ana Lúcia Miluzzi Yamada ${ }^{1}$ (D); Marcelo Pinheiro²; Geissiane Moraes Marcondes ${ }^{1}$; \\ Nicole Fidalgo Paretsis ${ }^{1}$; Luis Cláudio Lopes Correia da Silva ${ }^{1}$ \\ ${ }^{1}$ Universidade de São Paulo, Faculdade de Medicina Veterinária e Zootecnia, Departamento de Cirurgia, São Paulo - SP, Brasil \\ ${ }^{2}$ Médico Veterinário Autônomo, São Paulo - SP, Brasil
}

\begin{abstract}
Mineralization of the anatomical structures involved in the limb movement of horses has been reported to induce lameness and interfere with athletic performance. A 4-year-old jumping horse in sport activity was reported at Veterinary Hospital of University of São Paulo, with mild lameness and a mineralized oblique distal sesamoidean ligament (ODSL) of the left forelimb, revealed by a purchase radiographic and ultrasound examination. Mineralization is more common in tendons than ligaments. This report calls for attention to these structures when performing image exams, even in mild lameness. Long-term favorable follow-up by ultrasonographic and radiographic examination showed that the severe ligament injury in this case did not decrease the athletic activity until the present day.
\end{abstract}

Keywords: Calcification. Purchase examination. Fetlock. Desmopathy. Horse lameness.

\section{RESUMO}

A mineralização de estruturas anatômicas envolvidas na movimentação dos membros predispõe à claudicação e interfere no desempenho atlético. Foi admitido no Hospital Veterinário da Faculdade de Medicina Veterinária e Zootecnia da USP-SP um equino macho, da raça Brasileiro de Hipismo, com quatro anos de idade e histórico de claudicação leve e ligamento sesamoideo oblíquo distal mineralizado do membro torácico esquerdo, diagnosticado por exame de compra. A mineralização apresenta alta incidência em tendões, sendo em menor proporção nos ligamentos. Esse relato visa atentar à essas estruturas ao se realizar exames rotineiros de imagem, apesar de claudicação leve. $\mathrm{O}$ acompanhamento a longo prazo por ultrassonografia e radiografia mostrou que lesões graves de ligamentos, como no presente caso, não diminuíram a atividade atlética até o momento.

Palavras-chave: Calcificação. Exame de compra. Articulação metacarpofalangeana. Desmopatia. Claudicação.

Correspondence to:

Luis Cláudio Lopes Correia da Silva

Universidade de São Paulo, Faculdade de Medicina Veterinária

e Zootecnia, Departamento de Cirurgia

Av. Prof. Dr. Orlando Marques de Paiva, 87, Cidade

Universitária

CEP: 05508-270, São Paulo - SP, Brasil

e-mail: silvalc@usp.br

Received: June 28, 2019

Approved: September 20, 2019
How to cite: Marsiglia MF, Yamada ALM, Pinheiro M, Marcondes GM, Paretsis NF, Silva LCLC. Radiographic and ultrasonographic imaging of a dystrophic mineralization on the oblique sesamoidean ligament in a jumping horse. Twenty months follow-up. Braz J Vet Res Anim Sci. 2019;56(4):e159455. https://doi.org/10.11606/issn.16784456.bjvras.2019.159455

A 4-year-old Brazilian Sport Horse gelding was referred to the Veterinary Hospital of the University of São Paulo with history of joint fragment, seen at radiographic evaluation 
during a purchase examination. The horse was involved in intense athletic activities, with daily training for show jumping competitions. The radiographic changes observed were an osteochondritis dissecans on palmar aspect of the left metacarpophalangeal joint. At the hospital, when the horse was trotted in a straight line, a grade 1/5 lameness on the left forelimb (based on American Association of Equine Practitioners, 1991) was observed and response to fetlock flexion test exacerbated to $3 / 5$. No signal of effusion or swelling was present.

Ultrasonographic evaluation was performed on distal pair of fore and hind limbs including weight bearing transverse and longitudinal grayscale scans, using a linear array transducer (LA435, 10MHz, MyLab ${ }^{\mathrm{TM}} 30$ Gold VETE saote, Italy). Ultrasound exam showed desmitis on oblique sesamoidean ligaments (OSL) of the left forelimb, in addition to irregularities on the metacarpal joint. Evaluation of fiber pattern showed a disruption on lateral branch of OSL. Other findings were severe thickening and heterogenicity of the articular capsule, joint effusion and increased cellularity at synovial fluid. Left OSL was heterogenic (Figure 1B) and with increased vascular activity nearby (Figure 2), suggesting local inflammation. To compare, an ultrasound examination was performed in the oblique sesamoidean ligament of the contralateral limb.

To confirm the previous diagnosis, metacarpophalangeal joint radiographic examination (Sound Eklin Digital Min X Ray ${ }^{\circledR}$, Mark IIG, TR90, Illinois, USA; 80 kVp, 3.2 mAs) was repeated at the hospital. The exam revealed a circumscribed radiopaque mass near the sesamoid bones (Figures 3 and 4). The delimited areas measured approximately three centimeters (Figure 3). It was hypothesized that could be an osteochondral fragment or calcification involving OSL.

An arthroscopy was performed to explore the joint and possibly remove the fragments or the mineralized mass.
The fragments could not be visualized or removed since it was extracapsular. No significant interference with the cartilage surface was observed. Due to the involvement of synovial structures, hyaluronic acid was injected intra-articularly. For the post-operative period, amikacin sulphate ( $15 \mathrm{mg} / \mathrm{kg} \mathrm{IV}$, q24, for 5 days), phenylbutazone ( $4.4 \mathrm{mg} / \mathrm{kg}$ IV, q24, for 3 days) and omeprazole $(3.0 \mathrm{mg} / \mathrm{kg}$, q24, for 30 days) were administered. A sterile, padded bandage was applied to the distal aspect of the limb and maintained to protect for up to 15 days.

The horse was discharged after four days with orientation of 15 days rest and 90 days of progressive exercise. Besides that, oral administration of chondroitin sulphate was recommended and another two-joint injection of hyaluronic acid, one after 15 days and other after four months. Thereafter, the animal returned to its normal training program.

At the three-month follow-up, we observed a heterogeneous and thickened joint capsule, mineralization of the OSL, synovial proliferation, irregularity of the lateral third metacarpal condyle, and plica thickening.

Radiographic and ultrasound examinations were continuously performed every three months. The mineralization areas kept well-delimited on radiography (Figure 4) and showed no modification on the ultrasonographic pattern. Despite the mineralized tissue being delimited, the animal did not show pain or severe lameness. This study has 20 months of follow-up and the horse remains asymptomatic with its athletic activities.

In athletic horses, injuries on the ODSL are more frequent than in the straight ligament (SDSL). Sampson et al. (2007) highlighted the quantity and variety of horse athletic endeavors with injured distal sesamoidean ligament that may be relatively common, and when affected, may induce desmitis of one or both ligaments, mostly involving the medial branch of the forelimb (Brokken et al. 2008;
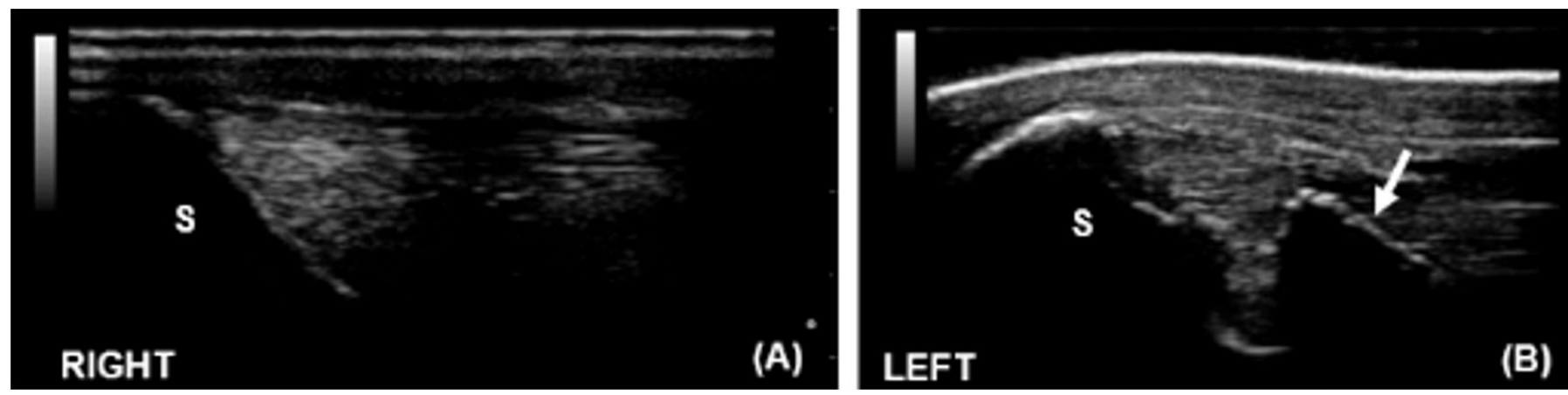

Figure 1 -(A) Grey-scale ultrasound mode B, longitudinal plane image of the right forelimb (normal) lateral oblique sesamoidean ligament. The ligament is of normal appearance, size and structure. (B) Ultrasonographic image of the left forelimb, lateral oblique sesamoidean ligament (calcified - arrow). The lateral sesamoid is smooth in outline and can be visualized easily on the left side of the image (S). There is hyperechogenic material, consistent with mineralization, on the proximal aspect of the sesamoid (arrow). Irregularity on the tendon face of the lateral sesamoid. S: sesamoid. 


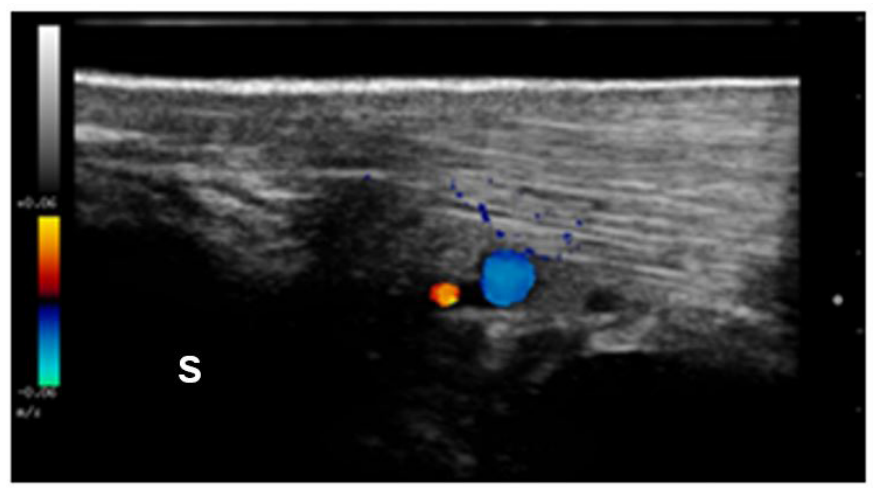

Figure 2-Longitudinal color Doppler ultrasound images demonstrating neovascularization in chronically injured oblique sesamoidean ligament on the left forelimb at the same level as demonstrated in Figure 1B. S: Sesamoid.
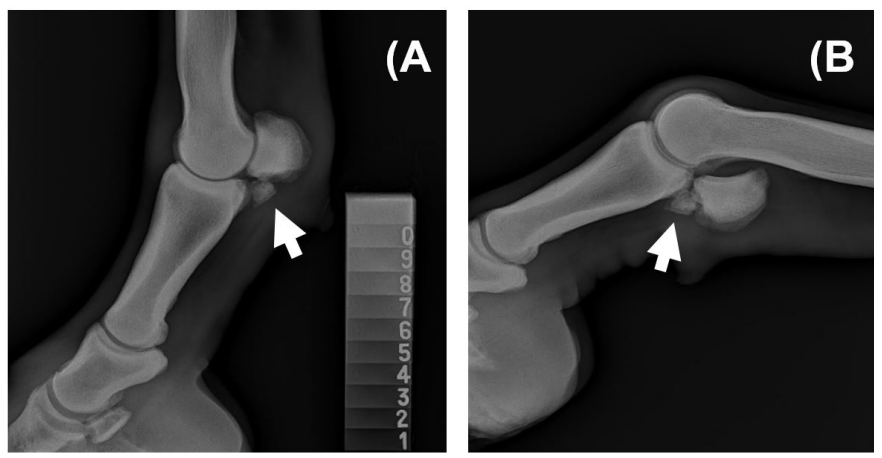

Figure 3 - (A) Lateromedial radiographic view of the left forelimb fetlock with the mineralized area below the base of lateral sesamoid (arrow). Aluminum scale was used to compare the bone density of the mass with the third metacarpus bone; (B) flexed lateromedial radiographic view of the same limb ( $80 \mathrm{kVp}, 3.2 \mathrm{mAs})$.
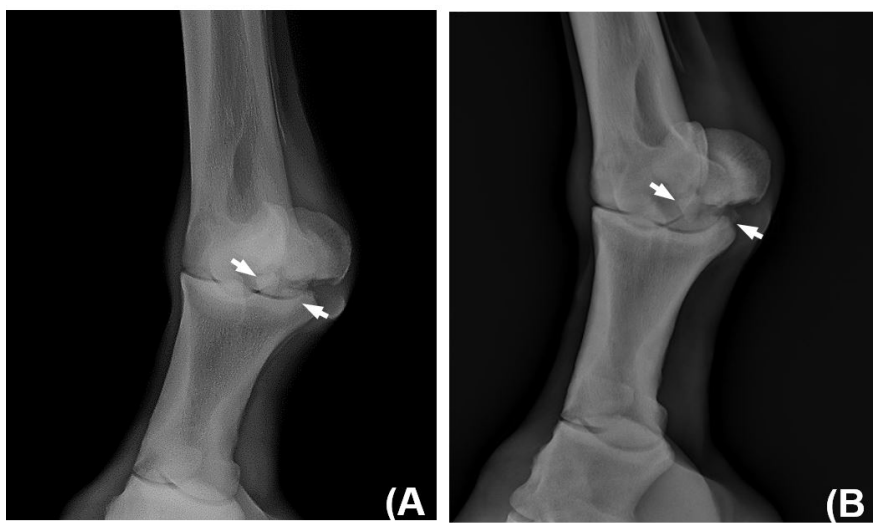

Figure 4 -Dorsolateral-palmaromedial oblique view of the left forelimb fetlock; (A) Image exam at the first evaluation; (B) after 20 months of follow-up ( $80 \mathrm{kVp}, 3.2 \mathrm{mAs})$.

Sampson et al., 2007; Vanderperren \& Saunders, 2009). Study using MRI (Sampson et al., 2007) confirmed that lesions in ODSL are frequent than in SDSL. In comparison between the branches, the frequency of lesions was equal, $67 \%$ (8 of 12), although more in the hindlimb. In our case, the ultrasound exam of left forelimb revealed an unaffected SDSL, supporting the before-mentioned hypothesis. In contrast, the lateral branch of distal sesamoidean ligament analysis showed severe injury. Comparison between limbs should be performed routinely on ultrasonographic evaluation (Redding, 2001), to establish the normal dimensions of individual anatomical variations (Carnicer et al., 2013; Gonzalez et al., 2010; Mitchell, 2009; Vanderperren \& Saunders, 2009). Contralateral forelimb and hindlimb imaging exams were accomplished and compared with the injured one (Figure 1), neither of them had ligament injury.

The distal sesamoidean ligaments are part of the suspensory apparatus and limit the extension, collateral motion and rotation of the fetlock joint during the stance phase (Carnicer et al., 2013; Denoix, 1994; Vanderperren \& Saunders, 2009). In athletic horses, the hyperextension is common, sometimes even touching the ground. Trauma in the soft tissues involved may lead to mineralization (Anderson, 2018; Dyson, 2018; Garvican et al., 2016). We hypothesized that this repeated trauma led to a desmitis and may be the origin of mineralization on ODSL (Figure 1).

Desmitis of the distal sesamoidean ligaments were described in a MRI study including 27 lame horses (Sampson et al. 2007). The return to athletic activity indicates that the prognosis is not as poor as previously reported (Kainer, 2002; Sampson et al., 2007; Schneider et al., 2003). The athletic performance of the horse in our report was not impaired. We recommended a physiotherapeutic regimen and accompaniment, including image examination, throughout the horse's career.

The image revealed in radiographic exam in Figure 3 has been reported in many studies (Brokken et al., 2008; Butler et al., 2017; Garvican et al., 2016; Vanderperren \& Saunders, 2009). Nonarticular base sesamoid bone fractures have been implicated as a source of chronic and persistent lameness (Anderson, 2018; Brokken et al. 2008), and it was for this reason that we investigated the mineralized area. We performed arthroscopy surgery and confirmed the nonarticular location.

Ultrasonography is the gold standard for diagnosis of tendon injuries in both man and horse (Dyson, 2018; Kristoffersen et al., 2005; Öhberg et al., 2001; Redding, 2001). In studies with human Achilles tendon, neovascularization is present in chronically painful tendinitis (Öhberg et al., 2001). Since these neovessels have not been found in pain-free tendons, this indicated the importance for the pain suffered (Kristoffersen et al., 2005; Öhberg et al., 2001). Neovascularization is frequently seen in areas with ultrasonographic changes (Kristoffersen et al., 2005), as color flow is related to blood 
flow (Öhberg et al., 2001). In our case, blood flow was observed in the injured limb (Figure 2), as we performed ultrasound exam in the oblique sesamoidean ligaments of both forelimbs to compare each other. The horse only showed mild lameness in flexion, without pain due to possible inflammation

The etiology of mineralization is uncertain. It can develop following tendon rupture or surgery and has been found in degenerative tissues (Zhang et al., 2016; Webbon, 1977). By classification, there are two types of mineralization: dystrophic or metastatic. Dystrophic occurs secondarily to trauma, hemorrhage or inflammation and may lead to calcification. Dystrophic mineralization is suggested to be a deposition of mineral in injured, degenerated or necrotic soft tissue. Metastatic mineralization is the deposition of mineral in structures such as muscles, tendons and connective tissue. Metastatic mineralization is deposited as a result of calcium-phosphorous imbalance, hereditary factors, hyperparathyroidism or renal disease (Dyson, 2011). Considering this, we suggest that, in the present case of an athletic horse, trauma is the first hypothesis of injury characterizing a dystrophic mineralization. For definitive diagnosis of mineralization, a histopathological examination is required (Landis et al., 1996), but is impractical in most clinical cases (O'Brien \& Smith, 2018). It can be suggested by ultrasonography with an increased echogenicity and presence of acoustic shadows (Smith \& Singer, 2007). In this case, since we did not remove the material surgically, the histopathological examination was not performed, diagnosis could only be suggested by the acoustic shadow between ligament fibers (Figure 1B).

\section{References}

American Association of Equine Practitioners. Guide for veterinary service and judging of equestrian events. 4th ed. Lexington, KY: American Association of Equine Practitioners; 1991.

Anderson JDC. The palmar/plantar aspect of the proximal phalanx - a site of a variety of bone and soft tissue pathologies. Equine Vet Educ. 2018;30(8):1-5. http://dx.doi.org/10.1111/eve.12882.

Brokken MT, Schneider RK, Tucker RL. Surgical approach for removal of nonarticular base sesamoid fragments of the proximal sesamoid bones in horses. Vet Surg. 2008;37(7):619-24. http://dx.doi.org/10.1111/j.1532950X.2008.00427.x. PMid:19134083.
In conclusion, despite the extensive lesions observed in the imaging studies, the unaltered clinical presentation of the horse was preponderant for the treatment chosen, avoiding the open intervention to remove the mineralized area. In this case, the severe oblique sesamoidean ligaments alteration did not interfere in athletic performance of the horse to the present day. However, it must be assisted periodically by physical exam, radiographic and ultrasonographic examinations, as well as the function of the metacarpophalangeal joint, aiming to intercede early with adequate joint therapy at the first signs of pain and lameness.

\section{Conflict of Interest}

The authors of this study declare that there is no conflict of interest regarding the publication of this manuscript.

\section{Ethics Statement}

The article submitted to Brazilian Journal of Veterinary Research and Animal Science entitled had been evaluated and approved by the Ethics Committee of the Veterinary Medicine and Animal Science School (FMVZ) from University of São Paulo, São Paulo-Brazil, under protocol CEUA 8840030417.

\section{Acknowledgements}

The authors would like to thank the Foundation for Research Support São Paulo (FAPESP) for the financial support (process number 2017/07255-5) and CAPES (Coordination for the Improvement of Higher Education Personnel) for the scholarship.

Butler JA, Colles CM, Dyson SJ, Kold SE, Poulos PW. Clinical radiology of the horse. 4th ed. West Sussex, UK: John Wiley \& Sons; 2017.

Carnicer D, Coudry V, Denoix JM. Ultrasonographic examination of the palmar aspect of the pastern of the horse: sesamoidean ligaments. Equine Vet Educ. 2013;25(5):256-63. http://dx.doi.org/10.1111/j.20423292.2012.00383.x.

Denoix JM. Functional anatomy of tendons and ligaments in the distal limbs (manus and pes). Vet Clin North Am Equine Pract; 1994;10(2):273-322. http://dx.doi.org/10.1016/ S0749-0739(17)30358-9 
Dyson S. Suspensory branch injuries in sports horses and racehorses. Uk-vet Equine. 2018;2(3):90-6. http://dx.doi. org/10.12968/ukve.2018.2.3.90.

Dyson SJ. Radiography and radiology. Diagnosis manag lameness horse. 2nd ed. St. Louis, Missouri: Elsevier Saunders; 2011. p. 168-81.

Garvican ER, Wylie CE, Payne RJ, Smith RKW, Head MJ. Mineralization of the equine palmar/plantar annular ligament treated by surgical resection. Vet Surg. 2016;45(5):602-8.

Gonzalez LM, Schramme MC, Robertson ID, Thrall DE, Redding RW. MRI features of metacarpo(tarso) phalangeal region lameness in 40 horses. Vet Radiol Ultrasound. 2010;51:404-14.

Kainer RA. Functional anatomy of equine locomotor organs. In: Stashak TS, editor. Adams' lameness in horses. 5th ed. Philadelphia, PA: Lippincott, Williams \& Wilkins; 2002. p. 11-3.

Kristoffersen M, Öhberg L, Johnston C, Alfredson H. Neovascularisation in chronic tendon injuries detected with colour Doppler ultrasound in horse and man : implications for research and treatment. Knee Surg Sports Traumatol Arthrosc. 2005;13(6):505-8. http://dx.doi.org/10.1007/ s00167-005-0648-3. PMid:15864547.

Landis WJ, Hodgens KJ, Song MJ, Arena J, Kiyonaga S, Marko M, Owen C, McEwen BF. Mineralization of collagen may occur on fibril surfaces: evidence from conventional and high-voltage electron microscopy and three-dimensional imaging. J Struct Biol. 1996;117(1):24-35. http://dx.doi. org/10.1006/jsbi.1996.0066. PMid:8776885.

Mitchell RD. Imaging considerations in the purchase examination of the performance horse. AAEP Proc. 2009;55:296-300.

O'Brien EJO, Smith RKW. Mineralization can be an incidental ultrasonographic finding in equine tendons and ligaments. Vet Radiol Ultrasound. 2018;59(5):613-23.

Öhberg L, Lorentzon R, Alfredson H. Neovascularisation in Achilles tendons with painful tendinosis but not in normal tendons: an ultrasonographic investigation. Knee Surg Sports Traumatol Arthrosc. 2001;9(4):233-8. http:// dx.doi.org/10.1007/s001670000189. PMid:11522081.
Redding W. Use of ultrasonography in the evaluation of joint disease in horses. Part 1: indications, technique and examination of the soft tissues. Equine Vet Educ. 2001;13(4):198204. http://dx.doi.org/10.1111/j.2042-3292.2001.tb00090.x.

Sampson SN, Schneider RK, Tucker RL, Gavin PR, Zubrod CJ, Ho CP. Magnetic resonance imaging features of oblique and straight distal sesamoidean desmitis in 27 horses. Vet Radiol Ultrasound. 2007;48(4):303-11. http://dx.doi. org/10.1111/j.1740-8261.2007.00247.x. PMid:17691627.

Schneider RK, Tucker RL, Habegger SR, Brown J, Leathers CW. Desmitis of the straight sesamoidean ligament in horses: 9 cases (1995-1997). J Am Vet Med Assoc. 2003;222(7):973-7. http://dx.doi.org/10.2460/javma.2003.222.973. PMid:12685789.

Smith SJB, Singer ER. Mineralisation of the biceps brachii tendon in a 6-year-old Cob mare. Equine Vet Educ. 2007;19(2):74-9. http://dx.doi.org/10.2746/095777307X181348.

Vanderperren K, Saunders JH. Diagnostic imaging of the equine fetlock region using radiography and ultrasonography. Part 2: the bony disorders. Vet J; 2009;181:123-36. http:// dx.doi.org/10.1016/j.tvjl.2008.03.005.

Webbon PM. A post mortem study of equine digital flexor tendons. Equine Vet J. 1977;9(2):61-7. http://dx.doi. org/10.1111/j.2042-3306.1977.tb03981.x. PMid:862604.

Zhang K, Asai S, Hast MW, Liu M, Usami Y, Iwamoto M, Soslowsky LJ, Enomoto-Iwamoto M. Tendon mineralization is progressive and associated with deterioration of tendon biomechanical properties, and requires BMP-Smad signaling in the mouse Achilles tendon injury model. Matrix Biol. 2016;52-54:315-24. http://dx.doi.org/10.1016/j. matbio.2016.01.015. PMid:26825318.

Financial Support: Thanks to the Foundation for Research Support São Paulo (FAPESP) - process number 2017/07255-5 for financial support.

Authors Contributions: Geissiane Moraes Marcondes, Marcelo Pinheiro and Nicole Fidalgo Paretsis participated in clinical activities and image acquisition. Marilia Ferrari Marsiglia, Ana Lúcia Miluzzi Yamada, and Luis Cláudio Lopes Correia da Silva participated in clinical activities, writing and reviewing this manuscript. 